\title{
Oceny moralne w procesie wyrokowania przez sąd karny
}

Paweł Mazur (Adam Mickiewicz University)

\section{Wprowadzenie}

Proces karny stanowi uporządkowany ciąg czynności, prowadzący do rozstrzygnięcia o odpowiedzialności karnej osoby postawionej w stan oskarżenia. Zasadniczym celem tego postępowania jest realizacja dyrektywy trafnej represji karnej. Znajduje ona wyraz w czterech postulatach:

- nikt niewinny nie powinien ponosić odpowiedzialności,

- nikt winny nie powinien ponosić odpowiedzialności większej, niż na to zasłużył,

- nikt winny nie powinien ujść odpowiedzialności,

- nikt winny nie powinien ponosić odpowiedzialności mniejszej, niż na to zasłużył (Cieślak 1984, 212-213).

Orzeczenia sądowe, które powinny realizować wskazane postulaty, są kształtowane i ogłaszane $\mathrm{w}$ trakcie istotnej fazy postępowania sądowego, mianowicie wyrokowania. Jest on sformalizowany i skonwencjonalizowany przez normodawcę. Składa się z następującej sekwencji nakazanych czynności: 1. narady nad wyrokiem, 2. głosowania składu orzekającego, 3. sporządzenia wyroku na piśmie, 4. podpisania i wreszcie ogłoszenia wyroku, a następnie 5. podania ustnie jego motywów i wreszcie 6. pouczenia o środkach zaskarżenia (Janusz-Pohl 2013, 6). Upoważniony organ wydając wyrok autorytatywnie stwierdza, czy doszło do przekroczenia normy sankcjonowanej, jak również, czy zachodzą okoliczności wyłączające karalność, winę, czy bezprawność. Następnie czyni użytek $\mathrm{z}$ normy sankcjonującej, upoważniającej do wymierzenia kary. Co istotne, sąd po rozpoczęciu postępowania sądowego, nie może uchylić się od wydania rozstrzygnięcia. Norma kompetencyjna, zobowiązująca do rozstrzygnięcia o odpowiedzialności karnej podsądnego, jest bowiem sprzężona $\mathrm{z}$ normą nakazującą $\mathrm{w}$ określonych okolicznościach uczynić z niej użytek (Ziembiński I 1980, 155). Organ wyrokujący w sprawie nie może przeto uchylić się od podjęcia decyzji co do odpowiedzialności moralnej jednostki wskutek własnych wątpliwości, bądź trudności w ustaleniu prawdy materialnej. Natomiast $\mathrm{w}$ dyskursie pozasądowym można mnożyć liczne wątpliwości co do tego, czy oskarżony z racji powszechnie znanej ułomności ludzkiej natury, nieprawidłowej socjalizacji czy internalizacji norm społecznych, skrajnie trudnej sytuacji bytowej itd. może ponosić odpowiedzialność, a jeśli, to $\mathrm{w}$ jakim zakresie. Optyka organu władzy 
sądowniczej jako odpowiedzialnego za dobro całej wspólnoty i strzeżenie dóbr dlań najcenniejszych jest zgoła odmienna. Jej walory uwypukla obszerny passus Hannah Arendt:

To dobrze, że prawo nie karze za grzechy zaniechania i że żaden ludzki sąd nie jest zwołany dla ferowania wyroków w ich sprawie. Ale dobrze również, że wciąż istnieje w społeczeństwie jedna instytucja, której unikanie kwestii osobistej odpowiedzialności jest niemal niemożliwe, gdzie wszelkie usprawiedliwienia abstrakcyjnej natury - od Zeitgeist do kompleksu Edypa - załamują się, gdzie osądzane są nie systemy, nurty czy grzech pierworodny, ale ludzie z krwi i kości, jak ty i ja, których czyny pozostają oczywiście czynami ludzkimi, ale którzy pojawiają się przed trybunałem, ponieważ złamali jakieś prawo uważane przez nas za ważne (Arendt 2006, 55).

Wyrokowanie stanowi realizację (zapożyczając się terminologicznie u Josepha Raza) funkcji pierwotnej prawa, polegającej na zapobieganiu zachowaniom niepożądanym i zapewnianiu istnienia zachowań pożądanych. Raz scharakteryzował rzecz następująco:

Chociaż funkcja ta spełniana jest głównie przez prawa nakładające obowiązki, to czasem wymaga także praw nadających władzę. Prawo może nadawać pewną władzę i określać jej egzekwowanie lub powstrzymywanie się od egzekwowania w pewnych okolicznościach, ponieważ uznaje owo egzekwowanie za pożądane lub niepożądane" (Raz 2000, 169).

Finalizacja każdego postępowania sądowego poprzez wydanie rozstrzygającej decyzji stanowi nadto realizację Radbruchowskiej wartości bezpieczeństwa prawnego; w ten właśnie sposób prawo działa i tworzy ład prawny. Wydawanie orzeczeń kończących wszczęte postępowanie i rozstrzygające leżący u jego podstaw spór jest wszak nieodzowne do obowiązywania, skuteczności i niezawodności prawa w praktyce (Radbruch 2009). Stanowi także realizację jednej $\mathrm{z}$ ważnych wartości wewnętrznych prawa, a mianowicie pewności, że po wszczęciu postępowania sądowego decyzja zostanie przez sąd istotnie wydana (Wróblewski 1975, 97). Wyrokowanie w sprawach karnych warunkuje także posłuch dla norm sankcjonowanych prawa karnego. Zależność stosowania norm prawa karnego materialnego i materialnego obrazowo ujął Marian Cieślak, wskazując, że „bez procesu karnego prawo karne materialne byłoby jak strach na wróble" (Cieślak 1952, 9).

Niniejsze opracowanie zdaje sprawę $\mathrm{w}$ próby nakreślenia problematyki istotnej części procesu decyzyjnego w fazie wyrokowania, jaką stanowią osądy bądź oceny moralne. Ich wydawanie jest powiązane $\mathrm{z}$ funkcją wymiaru sprawiedliwości sprawowaną przez sądy (Ziembiński 1972, 164).

Wydawanie osądów moralnych na etapie wyrokowania jest połączone $\mathrm{z}$ normą nakazującą ich ferowanie. Ten obowiązek wynika $\mathrm{z}$ reguły 
instrumentalnego nakazu, nakazującej czynić wszystko, co stanowi warunek konieczny zrealizowania stanu rzeczy nakazanego przez normę wyraźnie ustanowioną (Ziembiński 1980 II, 170). Rzeczone wypowiedzi oceniające są konieczne dla ustalenia, czy zarzucane oskarżonemu zachowanie wypełnia znamiona przestępstwa i zasługuje na karę. Prawo karne, z racji spełniania funkcji ochronnej polegającej na zabezpieczaniu najcenniejszych dóbr społecznych oraz funkcji sprawiedliwościowej, związanej z wymierzaniem odpłaty za wyrządzone zło (Pohl 2013, 30-31) jest zatem silnie sprzężone z moralnością. Nie jest to oczywiście związek typu walidacyjnego. Ponadto, nie powinno ono polegać na tym, aby prawodawca inspirował się określoną doktryną moralną. Współczesny normodawca winien mieć na względzie to, że prawo podkreślające swoje związki $\mathrm{z}$ określoną moralnością bywa silnie represyjne (Wąsek 1984, 46). Ścisła zbieżność reguł moralnych i prawnych prowadzi wszakże do budowy ładu totalitarnego, kontrolującego zachowania zastrzeżone w innym razie dla moralności (Kołakowski 2006, 28). W polu zainteresowania racjonalnego normodawcy, a w konsekwencji - także sądu stosującego prawo - znajduje się jedynie pewna grupa zachowań, uznana za naruszającą reguły postępowania $\mathrm{z}$ określonymi dobrami prawnymi. Granice te wyznaczają normy Konstytucji, w szczególności zasada proporcjonalności, czy demokratycznego państwa prawa (Kaczmarek 2013, 273).

Zakres zachowań poddawanych ocenom moralnych $\mathrm{w}$ fazie wyrokowania jest zatem znacznie węższy, niźli zakres zachowań poddawanych ocenom moralnym, wydawanym w życiu codziennym. Jednakowoż nie redukuje to stopnia trudności $\mathrm{w}$ zakresie kształtowania ocen moralnych w porównaniu z dezaprobatą czy aprobatą moralną, okazywaną w praktyce dnia codziennego wobec zachowań innych ludzi, które są obojętnie z punktu widzenia prawa karnego. Z uwagi na trudność w stosowaniu przez sądy instytucji prawa karnego, skomplikowanie rzeczywistości społecznej, a także skutki osądu dla osoby osądzanej, jawi się ono jako wymagające o wiele większego trudu.

\section{Paragraf I}

Wydawanie osądów moralnych wpisuje się w model sądowego stosowania prawa, przyznający sądom swobodę w ustalaniu faktów, przy czym swoboda ta powiązana jest $\mathrm{z}$ kompetencją do dokonywania rozmaitych ocen. Działalność sadów orzekających w procesach karnych dalece odbiega od modelu monteskiuszowskiego, zgodnie z którym sędzia jest li tylko „ustami ustawy" i przeprowadza niejako mechanicznie akty subsumcji (Wróblewski 1988, 19). Znacznie bardziej prawdopodobny proceduralnie i psychologicznie będzie tu model kantowski, oparty na złożonym akcie „władzy sądzenia”. 
Ocenianie czy też wartościowanie moralne w procesie karnym jawi się jako czynność nieodzowna choćby $\mathrm{z}$ uwagi na otwartość semantyczną języka prawnego, w którym powstają kodeksy karne. Co istotne, współczesne kodeksy karne nie przedstawiają się jako kazuistycznie rozbudowane regulacje, drobiazgowo opisujące zakazane zachowania i nie pozostawiające sądowi swobody w ocenach, o interpretacjach nie wspominając.

Szczególną uwagę warto zwrócić na stosowane przez prawodawcę "luzy" o charakterze aksjologicznym w postaci klauzul generalnych. Służą one osiągnięciu elastyczności i zindywidualizowaniu procesu stosowania prawa (Leszczyński 1992, 147). Powyższa instytucja ma zwiększać zakres swobody w procesie stosowania prawa, dzięki odwołaniu się do otoczenia aksjologicznego, usytuowanego poza systemem prawnym (Wojciechowski 2004, 74). Rzeczywistość kryminalna nie daje się ująć bez reszty w sztywne ramy. Kompleksowa ocena tej rzeczywistości wymaga upoważnienia sądu do sądów wartościujących, czyli ocen. Intencją normodawcy jest zatem pozostawienie organowi wyrokującemu swobody w ocenach celem wypracowania i wydania orzeczenia stosownego do okoliczności zarzucanego przestępstwa, i co najważniejsze - orzeczenia sprawiedliwego.

Wartościowanie moralne $\mathrm{w}$ toku wyrokowania dotyczy wielu okoliczności jak np. rodzaju i stopnia winy, wymiaru i rodzaju kary. W niniejszym opracowaniu waga ocen moralnych zostanie przedstawiona w oparciu o dwie instytucje, mianowicie społecznq szkodliwość czynu oraz stan wyższej konieczności.

Jedną z najważniejszych klauzul generalnych jest właśnie społeczna szkodliwość czynu (karygodność). Karygodność stanowi cechę przysługującą klasie zachowań określonego rodzaju. Aby czyn zabroniony mógł zostać uznany za przestępstwo, musi odznaczać się określonym stopniem społecznej szkodliwości (Pohl 2013, 289). Na poziomie stanowienia norm prawnych ustawodawca tworzący dany typ czynu zabronionego generalizuje jego ujemnie społeczną treść (Radbruch powiedziałby - antywartość), wskazując z tego powodu tylko jej najbardziej typowe elementy. Społeczna szkodliwość zachowań jest zatem wcześniejsza aniżeli ustanowienie stosownego zakazu przez normodawcę (Kaczmarek 2013, 286), co z kolei przypomina Kelsenowską zasadę, podług której najpierw zaistnieć musi rodzaj nieprawości aby zasadne było utworzenie odnośnej normy prawnej. Wszelako interesujące nas oceny moralne dotyczą czynu ujętego in concreto. Sąd w każdym postępowaniu karnym ma obowiązek ocenić zachowanie oskarżonego przez pryzmat kryteriów społecznej szkodliwości czynu wskazanych przez normodawcę, a także ustalić jej stopień. Katalog okoliczności wyznaczających stopień społecznej szkodliwości czynu ma charakter zamknięty i został przez ustawodawcę określony $\mathrm{w}$ treści przepisu art. $115 \S 2$ k.k. Z tego przepisu dekodujemy normę kompetencyjną, nakazującą branie pod uwagę przez sąd mający ocenić stopień społecznej 
szkodliwości - rodzaj i charakter naruszonego dobra, rozmiary wyrządzonej lub grożącej szkody, sposób i okoliczności popełnienia czynu, wagę naruszonych przez sprawcę obowiązków, jak również postać zamiaru, motywację sprawcy, rodzaj naruszonych reguł ostrożności i stopień ich naruszenia. Powyższe kryteria służą ocenie konkretnego czynu. Co istotne, oceny moralne w tym wypadku winny dotyczyć każdego z tych elementów z osobna (Majewski 2007, 1169).

Nie miejsce tutaj na obszerne komentowanie praktycznej realizacji każdego z powyższych czynników. Dość przywołać ciążący na sądzie wyrokującym obowiązek oceny postaci zamiaru czy motywacji sprawcy. Podczas stopniowania społecznej szkodliwości, wśród elementów poddawanych ocenie istotne znaczenie ma ocena intencji działającego, motywów i zamierzeń, które skłoniły go do popełnienia przestępstwa (Pohl 2013, 114-115). Takie holistyczne ocenienie czynu pozwala uchwycić swoistość społecznej szkodliwości czynu, na którą składa się nie tylko zewnętrzne zachowanie, ale i określony przebieg oraz nastawienie psychiczne takie jak umyślność bądź nieumyślność (Kaczmarek 2013, 123). W tym wypadku, ocenom sędziowskim podlega postawa, czy sposób oceniania określonego stanu rzeczy przez sprawcę.

Sąd musi zatem każdorazowo podejmować trud oceny tego rodzaju zachowań i ustalać stopień ich społecznej szkodliwości. Tego rodzaju ewaluacja ma zasadnicze znaczenie dla losów oskarżonego. Przykładowo postępowanie, w którym ustalono znikomość karygodności, musi zostać umorzone (art. $1 \S 2$ k.k. w związku z art. 17 § 1 pkt 2 k.p.k.). Może się również okazać, że w wyniku wartościowania czyn odpowiadający znamionom przestępstwa o wysokiej społecznej szkodliwości in abstracto oceniony zostanie jako odznaczający się znikomą karygodnością. Przykładem niech będzie wyrok Sądu Apelacyjnego w Krakowie z dnia 18 stycznia 2011 roku, w którym uznano, że wartość skradzionego mienia nie przekraczała jednego złotego, co wpłynęło na przypisanie szkodliwości społecznej nie wyższej niż znikoma, mimo że czyn wedle przepisów kodeksu karnego stanowi zbrodnię (Krakowskie Zeszyty Sądowe 2011).

Innym przykładem obrazującym wagę ocen sędziowskich może być kazus ojca, który - pozbawiony władzy rodzicielskiej nad dzieckiem - podczas odwiedzin tegoż dziecka, podejrzewając u niego poważne schorzenie, tj. zapalenie płuc z powodu wysokiej temperatury ciała, zabrał dziecko wbrew woli matki do szpitala, naruszając w ten sposób jej prawo nadzoru. Tego rodzaju zachowanie wypełniające znamiona czynu zabronionego polegającego na uprowadzeniu dziecka (art. 211 k.k.) w konkretnym przypadku uznane zostało za w ogóle pozbawione społecznej szkodliwości (Kaczmarek 2006, 189).

Zdecydowanie rzadszym, acz wyrazistym przykładem wartościowania moralnego jest rozstrzyganie przez sąd, czy ma on do czynienia z tzw. sytuacją 
kontratypową i czy w związku z tym winien wydać orzeczenie. Kontratyp polega na faktycznej kolizji zachodzącej pomiędzy dwoma dobrami chronionymi prawne, a nadto - na konieczności poświęcenia jednego z kolidujących ze sobą dóbr prawnych. Wreszcie warunkiem przyjęcia kontratypu jest poświęcenie społecznie opłacalne $\mathrm{z}$ uwagi na uratowanie dobra cenniejszego od dobra poświęconego (Pohl 2007, 255); w skrajnym przypadku obydwa dobra mogą być równocenne. Przykładem instytucji kontratypu jest stan wyższej konieczności, który polega na poświęceniu jednego dobra prawnego na rzecz drugiego, przedstawiającego wyższą wartość, w celu uchylenia bezpośredniego dlań niebezpieczeństwa, i to w sytuacji, gdy nie można było temu niebezpieczeństwu zapobiec (art. 26 $\S 1$ k.k.). Trud oceny związany z ważeniem dóbr prawnych stanowi powód rzadkiego stosowania wyżej wymienionej instytucji w praktyce sądowniczej. Spory budzi wskazanie katalogu dóbr i ich hierarchii w konkretnej sytuacji. Nawet życie, jawiące się jako najwyższa wartość, nie zawsze w praktyce orzeczniczej ma prymat nad innymi wartościami (Wilk 2008, 38-41). Egzemplifikuje to przypadek przewodnika górskiego, który wyprowadził grupę ludzi $\mathrm{z}$ niebezpieczeństwa $\mathrm{w}$ bezpieczne miejsce. $\mathrm{W}$ trakcie akcji ratunkowej jeden z uczestników utknął na drabinie i odmówił kontynuowania dalszej drogi. Perswazja przewodnika okazała się bezskuteczna. W tej sytuacji przewodnik polecił zrzucenie go z drabiny, co umożliwiło bezpieczne dotarcie grupie do celu. W niniejszej sprawie osoba która wydała opisane polecenie została uniewinniona (Lachowski 2006, 74). Trudność w wydawaniu sądów moralnych $\mathrm{w}$ tym wypadku wiąże się $\mathrm{z}$ koniecznością rozstrzygania poważnych dylematów aksjologicznych dotyczących z reguły dóbr wysoce społecznie cenionych, takich, jak życie, zdrowie czy mienie. Stronienie od stosowania tej instytucji w wymiarze praktycznym stanowi świadectwo pewnego niedostatku kompetencji osądu moralnego i nie sprzyja podejmowaniu odważnych decyzji.

\section{Paragraf II}

Tak szeroki zakres władzy sędziowskiej w sferze ocen moralnych i ich konsekwencje dla dóbr prawnych obywateli, a także szeroko rozumiane konsekwencje społeczne - $w$ tym zaufanie pod adresem prawa - rodzą pytanie o granice swobody sędziowskiej. Nie ulega wątpliwości, że jest ona zakreślona stosunkowo szeroko. Normatywnym umocowaniem dla swobody sędziowskiej jest podległość sędziego wyłącznie Konstytucji i ustawom. Oznacza to instytucjonalną niezależność od nacisków opinii publicznej, organów władzy publicznej czy polityków. Temu uprzywilejowaniu powinny odpowiadać również pewne wymagania wobec praktyki sądowej. Sędzia winien zachować dystans wobec potocznych osądów moralnych i pozostać wierny Kantowskiemu lub Popperowskiemu etosowi krytycznego myślenia, 
które w wypadku wyrokowania staje się krytycznym myśleniem moralnym. Co więcej, powinien również $\mathrm{z}$ dystansem umieć odnosić się do uprzednich osądów moralnych czy przyzwyczajeń w zakresie orzekania. Ponadto, podmiot dokonujący ocen moralnych musi przestrzegać zasady bezstronności, która jednak nie oznacza obojętności, albowiem do wartościowania przecież dochodzi. Oceny prawników są nadto oparte na pewnych założeniach upraszczających, dotyczących $\mathrm{m}$. in, granic argumentacji, czyli ustalenia momentu, w którym uzasadnienie zostaje zakończone, niewspółmierności ocen (Zirk-Sadowski 1984, 131-159) itp.

Sąd nie może wydawać sądów moralnych poza kontekstem normatywnym i społecznym, w którym funkcjonuje. Realizacja tego postulatu może nastręczać pewne trudności. Próżno szukać jednego, uniwersalnego czy choćby spójnego systemu moralnego, jakim miałby kierować się sąd w swojej praktyce orzeczniczej. Niewielką użyteczną wykazuje też postulat kierowania się przez sędziego ocenami podzielanymi przez większość społeczeństwa; oceny nie są generalnie stabilnymi i uniwersalizowalnymi punktami orientacyjnymi dla innych ocen. Podmioty oceniające opierają swe oceny nawet te same pod względem wartości bezwzględnej negatywnej lub pozytywnej - na zróżnicowanych kryteriach i mają różny stopień nasilenia polegający na tym, że można coś aprobować mniejszym lub większym stopniu, choć mówimy ogólnie o "aprobacie". Zachodzi poważna trudność w ustaleniu w drodze operacji arytmetycznych preferencji społeczeństwa (Kaczmarek 2013, 283). Moralność społeczna jest dynamiczna podobnie, jak moralność indywidualna; jest ona od tej ostatniej nieskończenie bardziej złożona. Jest ona ponadto konglomeratem moralności grupowych różnych grup i warstw społecznych. Współczesne społeczeństwo jest raczej procesem fuzji różnych kultur i przemieszania się grup społecznych aniżeli gotowym i definiowalnym bytem. Nie istnieje żaden jednolity i konsekwentny system społeczny (Reichenbach 1975, 97). Sędzia, wydając sądy moralne, musi zatem mieć na względzie coś, co określić można jako minimalizm moralny prawodawcy. Normodawca, który ma godzić rozmaite, a niekiedy sprzeczne interesy i wartości w normach przewyższających owe partykularyzmy, nie może dążyć do realiacji określonych ideałów moralnych; być może na tym właśnie zasadza się jego własna etyka i generalnie etyka profesji prawnych. Prawodawca nie chroni takich dóbr zrelatywizowanych do pewnych standardów perfekcjonistycznych i zwanych niekiedy cnotami, jak szlachetność, prawdomówność, lojalność czy uczciwość (Lang 1990, 36). W tej materii wymogi pod wobec prawa jako systemu normatywnego są sformułowane o wiele powściągliwiej. Prawo winno zapewniać prawidłowe, bezkolizyjne współżycie ludzi w społeczeństwie (Ziembiński, 54-56). I w tych minimalnie zakreślonych granicach powinny oscylować niezbędne do jego wewnętrznego funkcjonowania sądy moralne. 
Ramy dla wartościowania moralnego w prawie są zatem zakreślone w sposób bardzo ostrożny, nieostry i ogólny. Wydaje się, że inaczej być nie może. Respektowanie niezawisłości sędziowskiej, a także celów stawianych procesowi karnemu uniemożliwia wyznaczanie tutaj ścisłych kryteriów. Nie oznacza to jednak, że racjonalny prawodawca nie skonstruował mechanizmów kontrolnych. Arbitralności sądów przeciwdziała nakaz sporządzenia uzasadnienia do wyroku, w którym sąd musi zdać relację z toku rozumowania moralnego, które doprowadziło go do takich a nie innych ocen. Na sądzie karnym ciąży powinność uzasadnienia swojego stanowiska zgodnie z zasadami racjonalności i dyskursywności, a zatem w zgodzie wymogami ścisłej artykulacji, a także konsekwencji (Szaniawski 1983, 8-9). Motywy orzeczenia w sferze moralnej, tak jak całe uzasadnienie wydanego wyroku, muszą odpowiadać wymaganiom intersubiektywnej kontrolowalności i komunikowalności (Zieliński 1975, 141-145)

Co istotne, uzasadnienie orzeczenia nie jest adresowane wyłącznie do prawników orzekających w sądzie wyższej instancji, kontrolujących prawidłowość rozumowania sądu pierwszej instancji ani też tylko do profesjonalistów świadczących pomoc prawną. Ma ono bowiem na celu przedłożenie i przedstawienie społeczeństwu racji przemawiających za orzeczeniem. Ta powinność nabiera szczególnej wagi wobec wzrastającej nieufności do władzy sądowniczej. Łętowska słusznie przeto podkreśliła, że orzeczenia wprawdzie "komunikowane” ale pozbawione uzasadnienia stoją na przegranej pozycji (Łętowska 1998, 12). Przekonujące uzasadnienia osądów moralnych mogą także wpływać na postawy moralne adresatów norm prawnych, w tym na poczucie zobowiązania w stosunku do prawa. Refleksja sędziowska winna wszakże spełniać wyższe standardy od często powierzchownych, arbitralnych osądów formułowanych w życiu potocznym. Winna ponadto wyznaczać reguły postępowania $\mathrm{z}$ dobrami społecznie cenionymi i w sposób jasny komunikować je członkom społeczeństwa. Osądy moralne powinny odznaczać się uniwersalizowalnością. Oznacza ona, że sądy moralne winny być adekwatne dla osób znajdujących się w takiej samej sytuacji (Pietrzykowski 2011, 28). W orzecznictwie sądowym ta zasada ma silny związek z wartością jaką jest przewidywalność wydania określonej decyzji sądowej (Wróblewski 1988, 339).

Oceny sędziowskie nie mogą być efektem reakcji emocjonalnych sędziego, wywołanych np. drastycznymi okolicznościami popełnienia przestępstwa. Mimo to naiwnością byłoby ignorowanie tego, że rozstrzygnięcia sądu są również $w$ jakiejś mierze zależne od słabostek, chwilowych nastrojów podmiotu decyzyjnego czy rozmaitych, nieprzewidywalnych okoliczności. Oparte są częściowo również na nieuświadomionych przesłankach, czy intuicji moralnej (Pietrzykowski 2014, 67). Co więcej, pozycja prawnika dokonującego określonych ocen przypomina sytuację aktora. Aktor kieruje się nie tylko regułami 
postrzeganymi refleksyjnie, ale także zinternalizowanymi bezrefleksyjne zwyczajami i nawykami. Znaczna część zasad postępowania, jakimi kierują się prawnicy, jak zauważa Artur Kozak, ma charakter właśnie nieskodyfikowanych zwyczajów (Kozak 1999, 256). Konieczność sporządzania uzasadnień obliguje sąd do przedstawienia procesu jako racjonalnego właśnie, niezależnie od tego, że mogły nań wpływać rozmaite inne czynniki, nieuświadamiane lub pozaracjonalne. Refleksja, rozumowanie, wnioskowanie przeciwstawiane są uprzedzeniom, emocjom czy intuicjom.

\section{Paragraf III.}

Pozostaje jeszcze próba odpowiedzi na pytanie, od czego zależy zdolność sądu formułującego oceny moralne wyżej nakreślonym, dość trudnym skądinąd zadaniom. Normodawca, oprócz ukończenia stosownej edukacji prawniczej, sformułował jedynie oczekiwanie w zakresie osobowości sędziego. Jest to oczywiście istotne, ale - jak się dalej okaże - dalece niewystarczające dla zapewnienia odpowiedniego poziomu rozumowań i ocen moralnych. Od osób piastujących urząd sędziego, oprócz wylegitymowania się odpowiednimi kwalifikacji intelektualnymi, normodawca oczekuje, aby odznaczały się „nieskazitelnym charakterem”, co odzwierciedlać się być może nieposzlakowanej opinii (zob. art. $61 \S 1$ pkt 2 u.s.p.). Warunek ten jest najpierw weryfikowany $\mathrm{w}$ procedurze naboru kandydatów na stanowiska sędziowskie, a wtórnie - podczas postępowań dyscyplinarnych (Laskowski $2008,59)$. Tymczasem ustawodawca nie zawarł w przepisach definicji legalnej pojęcia „nieskazitelny charakter”. W komentarzu do ustawy Prawo o ustroju sądów powszechnych wymienia się cały wachlarz sędziowskich przymiotów. Wskazuje się między innymi na to, że kandydat na sędziego powinien być: uczciwy, pracowity, nieposzlakowany, zrównoważony, sumienny, odważny, cierpliwy, spokojny, bystry, uprzejmy, samokrytyczny, a także mieć optymistyczne usposobienie oraz unormowaną sytuację rodzinną (Gudowski, Ereciński 2013). Tego rodzaju wymagania kreują heroiczny wzorzec osobowy, w rzeczywistości trudno osiągalny. Taki katalog cech, które mają być kształtowane przez sędziego, nie ma, jak się wydaje, wielkiego znaczenia praktycznego dla doskonalenia sądów moralnych wypracowywanych przez sędziego. Wskazana nieskazitelność weryfikowana jest w zasadzie jedynie w sposób negatywny, zazwyczaj dopiero w sytuacji poważnego przekroczenia norm moralnych, to znaczy $\mathrm{w}$ sytuacji popełnienia przez sędziego przewinienia dyscyplinarnego. Sędzia nie jest zatem rozliczany za niedoskonalenie własnego charakteru, skądinąd słusznie, lecz jedynie za czyny godzące w godność jego urzędu i w opinię sędziowskiej profesji. Szukając optymalnych warunków do wydawania ocen moralnych, należy przenieść akcent ze swoistej etyki cnót jako trwałych przymiotów, promowanej przez normodawcę, na użyteczną i jak się wydaje nie dość 
docenianą w procesie wyrokowania - kompetencje osądu moralnego, która przypomina cnotę $\mathrm{w}$ rozumieniu dyspozycji działania, areté bądź też virtù w rozumieniu Arystotelesowskiej Etyki Nikomachejskiej. Zgodnie z definicją Kohlberga polegałaby ona na „zdolności podejmowania decyzji i formułowania sądów moralnych (tj. opartych na zasadach wewnętrznych) oraz działania w zgodzie z tymi sądami. Kompetencja do sądu moralnego jest rozwijana, bądź nie w ciągu całego życia. Jej rozwój jest zależny od odpowiedniej edukacji czy wychowania. Sprzyja temu dyskursywna przestrzeń" (Nowak, Lind 2008, 132133), a także regularne używanie. Teoretycznie sędziowie przez cały czas tworzą osądy i wydają wyroki, toteż jawią się jako osoby $w$ pełni ukształtowane i predysponowane do wykonywania swego zawodu. Być może dyskrecjonalność sędziowska, obok swobody ma również pewne ograniczenia, spowodowane zmianami proceduralnymi, które nie sprzyjają rozwojowi kompetencji moralno-dyskursywnych.

Otóż przejawem dyskursywności w ramach sformalizowanego procesu jest czynność narady sędziowskiej. Tymczasem nawet tak hermetyczna i skądinąd konieczna w procesie dyskursywność ustępuje miejsca wymogom rzekomej skuteczności i profesjonalizacji. Obserwujemy wszakże niepokojący trend prawodawczy do jednoosobowego orzekania przez sędziego i eliminowania tzw. czynnika społecznego, czyli ławników. W sposób istotny zubaża to możliwości rozwijania przez sędziów kompetencji dyskursywnych w tym zakresie. Walor kolegialności $\mathrm{w}$ orzekaniu podkreślił S. Waltoś wskazując, że wypowiadanie sądów w obecności innych biorących udział w naradzie stanowi głośne myślenie, zawiera element samokontroli, zawsze skłania do ostrożności w formułowaniu poglądu. „Oczy, uszy, a czasem i mimika postronnych to lustro, w którym odbija się wypowiedź" (Waltoś 2011, 529-530). Sędzia zatem w znakomitej większości spraw nie konfrontuje swojego rozumowania moralnego z rozumowaniem innych upoważnionymi do tego podmiotami. Nie uczestniczy on zatem w rzeczywistym dyskursie praktycznym, nie wystawia na próbę racjonalności swoich racji i przesłanek, które mogą się w ten sposób rozwijać, precyzować, doskonalić.

Oceny moralne stanowią ważną, wręcz zasadniczą część procesu poznawczego, podejmowanego przez sąd. Konsekwencje tego rodzaju wypowiedzi oceniających mają istotne znaczenie na pociągnięcie oskarżonego do odpowiedzialności karnej. Upoważnienie sądów do ich ferowania znajduje silne umocowanie w zasadzie niezawisłości i trafnej reakcji karnej. Nie ma zatem odwrotu od tego rodzaju sądów. Nakłada to jednak obowiązek kontrolowania poprawności ich dokonywania i rozwijania kompetencji do wydawania sądów moralnych. 


\section{Literatura}

Arendt, H. 2006. Odpowiedzialność i władza sq̨dzenia. Przeł. W. Madej, M. Godyń. Warszawa: Prószyński i Spółka.

Cieślak, M. 1952. Proces karny (skrypt). Warszawa: PWN.

—, 1984. Polska procedura karna. Warszawa: PWN.

Gudowski, T., Ereciński, J. Iwulski 2013. Prawo o ustroju sq̨dów powszechnych. Komentarz. Warszawa: Lexis Nexis.

Janusz-Pohl, B. 2013. „O wyroku nieistniejącym w polskim postępowaniu karnym". Państwo i Prawo, 12/2013.

Kaczmarek, T. 2013. „Dobro prawne i społeczna szkodliwość czynu”. W: Dębski, R. (red. naukowa). System prawa karnego. Część ogólna. Nauka o przestępstwie. Zasady odpowiedzialności. Warszawa: C.H. Beck.

—, 2006. Materialna treść przestępstwa jako problem kodyfikacyjny: Rozważania o przestępstwie i karze. Wybór prac z okresu 40-lecia naukowej twórczości. Warszawa: Kodeks.

Kozak, A.. 1999. „O pojęciu prawniczej władzy dyskrecjonalnej”. W: Leszczyński, L. (red.), Zmiany społeczne a zmiany w prawie. Aksjologia. Konstytucja. Integracja europejska. Lublin: Wydawnictwo Naukowe UMCS.

Kołakowski, L. 2006. Czy diabeł może być zbawiony i 27 innych kazań. Kraków: Znak.

Krakowskie Zeszyty Sadowe 2011, nr 5

Lachowski, J. 2005. Stan wyższej konieczności w polskim prawie karnym. Warszawa: C.H. Beck.

Leszczyński, L. 1992. „O aksjologii stosowania prawa”. W: Czech, B. (pod red.) Filozofia prawa a tworzenie $i$ stosowanie prawa. Katowice: Wydawnictwo Uniwersytetu Śląskiego.

Łętowska, E. 1997. „Pozaprocesowe znaczenie uzasadnień wyroków”. Państwo i Prawo, 5/1997.

Majewski, J. 2007. „Komentarz”. W: Zoll, A. (red. naukowa). Kodeks karny. Część ogólna. Warszawa: Wolters Kluwer.

Nowak, E., Mazur, P. 2014. The New Actuality of Judge Steinberg's Dilemma. Artykuł przyjęty na międzynarodową konferencję Moral Judgment Competence and Conflict Solving, Universität Konstanz, lipiec 2014.

Nowak, E., Lind, G. 2009. "Dyskursywna wolność a sąd moralny. O destruktywnym wpływie stanu wojennego na edukację demokratyczną wśród studentów". W: Cern, K. M., Juchacz, P. W., Nowak, E. (red. naukowa). Edukacja demokratyczna. Poznań: Wydawnictwo Naukowe IF UAM.

Pietrzykowski, T. 2011. Etyczne problemy prawa. Warszawa: Lexis Nexis.

—, 2014. Intuicja prawnicza. W stronę zewnętrznej integracji teorii prawa. Warszawa: Diffin. 
Pohl, Ł. 2007. Struktura normy sankcjonowanej w prawie karnym. Poznań: Wydawnictwo Naukowe UAM.

—, 2013. Prawo karne. Część ogólna. Warszawa: Lexis Nexis.

Radbruch, G. 2009. Filozofia prawa. Tł. E. Nowak. Warszawa: PWN.

Reichenbach, H. 1975. „O istocie ocen i norm moralnych”. W: LazariPawłowska, I. (pod red.) Metaetyka. Warszawa: PWN.

Raz, J. 2000. Autorytet prawa. Eseje o prawie i moralności. Warszawa: Dom Wydawniczy ABC.

Szaniawski, K. 1983. „Racjonalność jako wartość”. Studia Filozoficzne, 56/1983. Waltoś, S. 2011. „Ławnik - czy piąte koło u wozu?”. W: Grzegorczyk, T. (pod red.) Funkcje procesu karnego. Księga jubileuszowa Profesora Janusza Tylmana. Warszawa: Wolters Kluwer.

Wąsek, A. 1984. „Prawo karne - miminum moralności”. Annales UMCS S.G., Vol. XXXI, Issue 3/1984.

Wojciechowski, B. 2008. Dyskrecjonalność sędziowska. Studium teoretycznoprawne. Toruń: Adam Marszałek.

Wilk, L. 2008. „Aksjologiczne problemy stanu wyższej konieczności”. Państwo i Prawo, 11/2008.

Wróblewski, J. 1973. Wartość a decyzja sq̨dowa. Warszawa: PWN.

—, 1988. Sadowe stosowanie prawa. Warszawa: PWN.

Ziembiński, Z. 1972. Etyczne problemy prawoznawstwa. Warszawa: PWN.

—, 1980. Podstawowe problemy prawoznawstwa. Warszawa: PWN.

Zieliński, M. 1975. Poznanie sq̨dowe a poznanie naukowe. Warszawa: PWN.

Zirk-Sadowski, M. 1984. Rozumienie ocen $w$ języku prawnym. Łódź: Wydawnictwo Naukowe UŁ. 


\title{
Paweł Mazur (Adam Mickiewicz University)
}

\section{Moral judgments within trial process by criminal court}

\begin{abstract}
The article Moral judgments within processing by criminal court. An overview is designed to be an introduction to problems of moral evaluations within criminal process. It is stated that evaluations necessarily contribute to sentences' guilty or unguilty and judges pass them to achieve justice. Let us call chosen institutions of penal law to show how problematic axiological reasoning and evaluative procedures can really be. There is no universal or higher moral system in which judge's evaluations would be rooted. Each judge needs to develop his own moral judgment competence. Courts have to justify values-based sentences to make them convincing for the whole society.
\end{abstract}

Key-words: criminal process, moral evaluations, moral judgment competence, guilty, unguilty, convincing power, justification, justice

Ethics in Progress (ISSN 2084-9257). Vol. 4 (2013). No. 2. pp. 137-149. 